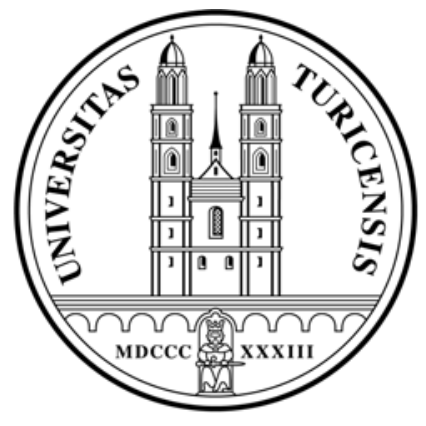

Institute for Empirical Research in Economics

University of Zurich

Working Paper Series

ISSN 1424-0459

Published in: Bruno S. Frey. Arts \& Economics:

Analysis \& Cultural Policy. 2nd Edition. Berlin et al.: Springer Verlag. 95-104. (2003)

Title: Private Faces in Public Places: A Case Study of the New Beyeler Art Museum

Working Paper No. 107

Pro-Social Behavior, Reciprocity or Both?

Bruno S. Frey and Stephan Meier

February 2002 


\title{
MUSEUMS BETWEEN PRIVATE AND PUBLIC THE CASE OF THE BEYELER MUSEUM IN BASLE
}

\author{
by \\ BRUNO S. FREY \\ STEPHAN MEIER \\ University of Zurich \\ Institute for Empirical Research in Economics \\ Blumlisalpstr. 10, 8003 Zurich, Switzerland \\ Phone: +41-1- 63437 30/31, Fax: +41-1-634 4907 \\ E-mail: bsfrey@iew.unizh.ch, smeier@iew.unizh.ch
}

(2 June 2002)

We are grateful for helpful comments from Matthias Benz, Reiner Eichenberger, Reto Jegen, Gebhard Kirchgässner and Simon Lüchinger. 


\title{
MUSEUMS BETWEEN PRIVATE AND PUBLIC
}

\author{
THE CASE OF THE BEYELER MUSEUM IN BASLE
}

\begin{abstract}
In Europe, ever more private museums are now entering the field. This paper investigates the behavior of one of these private museums, using an institutional approach of cultural economics. The Beyeler museum in Basle, Switzerland, is a privately founded art museum with an extraordinary collection of art works. Though less than five years old, it is acknowledged to be the most successful museum in Switzerland in terms of number of visitors.

However, the Beyeler museum is not completely private but receives public support. We analyze how this influences the museum's behavior: (1) The directorate of the Beyeler museum stays away from the art market with its collection as public institutions do. (2) The museum embarks on a self-propelling process concerning special exhibitions, therewith losing some of its uniqueness. (3) Concerning visitors' amenities, differences between private and public museums emerge but to a lesser extent than expected according to theory. (149 words)
\end{abstract}

JEL classification: Z1

Keywords: Museums, special exhibitions, state support, cultural economics 


\section{BEYELER IN TODAY'S MUSEUM WORLD}

Art museums have experienced dramatic changes over the last few decades. New museums have sprung up at an increasingly rapid rate. Whereas European museums were always institutions established by the state and were a part of the public sector, the situation has changed considerably. Now private museums increasingly set the tone, and the public museums have a hard time keeping up. ${ }^{1}$

The newly founded art museums have become part of a major leisure activity and nowadays compete with even the most popular sport events. Blockbuster exhibitions attract huge crowds and have become a major tourist attraction. ${ }^{2}$

The Beyeler Museum located in Riehen, canton Basle, is a new entrant into this field of activity. Founded by the successful art dealer, Ernst Beyeler, in 1997, the museum built by Renzo Piano hosts Beyeler's collection of 170 high quality works of Classical Modern art. Though less than five years old, it is generally acknowledged to be the most successful museum in Switzerland. In terms of attendances it outnumbers all the other Swiss museums including the big public organizations. Its curators boast that it belongs to the "first league" of art museums in the world. $^{3}$

What general insights about art museums can be obtained from this successful private foundation? This paper focuses on three aspects: the relationship of the collection to special exhibitions and the role architecture plays; how much the museum relies on the market to deal with the collection; and the amenities for visitors. The topic is approached from the point of

1 Public museums not only face stiff competition for visitors from the newly founded museums. Large and important private collections, which in former times would have been donated to the public organizations, now form part of newly founded private museums, in Switzerland e.g. the Rosengart collection in Lucerne, the Daros collection and the Flick collection in Zurich.

2 For example, in 2001, the exhibition 'Vermeer and the Delft school' attracted more than 8000 visitors daily in the Metropolitan Museum in New York (The Art Newspaper 2001). The exhibition altogether had 554’287 visitors.

3 For further information about the museum, see the internet www.beyeler.com. 
view of cultural economics ${ }^{4}$. The relationship between the private and the public aspects of the Beyeler Museum guides our inquiry. In what respect, and to what extent, does it matter whether such a museum is private or public? This question is of interest, because art museums take many different forms. There are cases of strictly public ownership (some of the most famous art museums in Europe are part of government bureaucracy), and there are art museums in a strictly profit-oriented environment (such as the art museum in the Bellagio Hotel in Las Vegas). Art museums thus constitute a testing ground for an institutionally based economic theory of museums. Depending on this analysis, it is possible to gain insights into museum policy.

Studying one particular museum, in particular a newly founded one, is faced with serious difficulties. Information is very restricted. Much of what would be relevant to know is not revealed to outsiders. Our formal request to receive the annual financial statement was rejected by the Beyeler museum, as well as by the public authorities granting the subsidies ${ }^{5}$. This is not accidental, but corresponds to the interests of the persons involved. Thus, the extent of information available reflects the institutional conditions. Even more fundamental are the problems connected with constructing counterfactuals, in particular how the museum would have evolved had the public influence been stronger. In order to be able to make certain comparisons and to approach our hypothesis empirically, we use the two recent survey data sets about Swiss museums compiled by Eugster (2000) and by the Kunstverein (1999).

The next section gives a short introduction on the economics of museums. From theory, we derive a certain hypothesis about the behavior of museums and, in particular, the museum's directorate. These hypotheses can be tested in the case of the Beyeler museum. Section III analyzes why this private museum is so closely linked up with the state. Section IV deals with three particularly striking and unexpected aspects. We look at collection policy and ask why it

\footnotetext{
4 We take it as a matter of course that various points of view are not only possible but also desirable, and that the respective studies might lead to quite different evaluations.

5 Letters of April 5, 2002 and April 22, 2002 to the first author.
} 
is isolated from the market: the body of the collection can under no circumstances be sold, the holdings are not valued in monetary terms, and lending out is not done for monetary compensation. Section V looks into the question of why a museum possessing such a high quality collection nevertheless embarks on organizing so many special exhibitions, most of them explicitly designed as blockbusters. Section VI deals with visitors' amenities which differ little between the private Beyeler museum and public museums. The last section offers general conclusions for museum policy.

\section{THE ECONOMICS OF MUSEUMS}

The present analysis is set within the confines of cultural economics, i.e. applies economic thinking to the arts. ${ }^{6}$ This approach to art is not restricted to financial aspects, such as subsidies and cost, but uses the economic model of human behavior (see Becker, 1976; Stigler, 1984; Hirshleifer, 1985; Frey, 1999) to enlighten the social aspects of art. People are assumed to behave rationally, in the sense that they react systematically to changes or differences in constraints connected to particular institutions.

As will become obvious, the present analysis of the economics of the arts differs greatly from the view taken by other social sciences, be it the sociology or psychology of art or art law. It is also fundamentally different from the art historians' perspective, which dominates the museum world: by far the largest percentage of "museologists" employed have had academic training in the history of art. Indeed, most art historians are not even aware that an economics of the arts exist, and when confronted with economic problems connected with the arts (of which there are plenty), they deal with them in a non-professional way.

6 See Feldstein (1991), and Special Edition of The Journal of Cultural Economics (1994/4). 
This article focuses exclusively on the supply of museum services. The main actors in a museum determining the museum services are the directorate and their professional staff. For the sake of simplicity, the discussion is restricted to the directorate. The directorate is concerned primarily with their own well-being (economically speaking, they are maximizing their utility function). The directors' utility depends on their own income and the prestige they get within their reference group, which consists mainly of art lovers and the international museum community. A second source of amenity is derived from the agreeable working conditions and job security. In order to explain the behavior of the museum directorate, the constraints they face must be taken into consideration.

The finances available are the most important constraint on the museum's directorate. Other constraints, such as the amount of space or legal and administrative burdens from the bureaucracy or labor unions can weigh heavily but, most importantly, museum spending is limited by the available budget. However, the sources of income differ widely from one museum to another. While some depend mostly on public grants, others rely exclusively on private money (donations and sponsorship, or income from entrance fees, shops and restaurants). ${ }^{7}$ From a politico-economic point of view, the institutional setup and the nature of funding of the museums has a dramatic influence on the behavior of the directorate. Most of the literature focuses on the extreme cases of a totally private and a totally public museum. The incentives for the museum directorate to behave in a certain way are completely different, depending on this institutional framework (see Frey and Pommerehne, 1989; Rosett, 1991).

7 Rosett (1991) presents evidence of the financing of U.S. museums, which supports the picture of the heterogeneous funding of museums. 
Directors of public museums rely exclusively on public grants. In practice, they not only receive sufficient funds to cover the expenses allotted to them in the budget, but have a deficit guarantee, at least to a certain extent. This institutional setting provides little incentive to generate additional income and to keep costs at a minimum. The directorate will not allocate energy and resources generating additional income, because any additional money goes back into the public treasury. If they were to make a surplus, the public grants would be decreased, which acts like an implicit tax of 100 percent on profits. The museum's management tends to move away from a commercial to a non-commercial framework in order to relieve the directorate of the pressure of having to cover costs with additional income. When the directorate is no longer forced to cover costs by its own efforts, it can legitimize its activities by referring to intrinsic 'artistic', 'scientific', or 'historical' values. This application of non-commercial standards helps the museum directors to achieve their goal of prestige, performance excellence and pleasant working conditions. From this institutional point of view, one would expect: (a) Public museums to distance themselves completely from the art market when managing their art collection (Frey, 1994, Montias, 1973). The directorate has no incentive to sell their paintings because firstly, they cannot use the income generated and secondly, activities are then measurable in monetary units, which leaves them open to criticism from outside (be it by politicians or by public administrators). (b) Directors of public museums to be less interested in the number of visitors because they are not dependent on income from entrance fees or shops. Exhibitions that attract large crowds are merely a by-product, because one actively aspires to gain prestige from the small group of art lovers. Therefore, exhibitions are designed to please an insider group of art 'freaks'. (c) As a consequence, that the visitors' amenities in public museums are poorly developed. Exhibitions are not presented well and restaurants, shops and the general attractiveness of, for example the entrance area, are disregarded. Little attention is paid to the profitability of museum shops, restaurants and cafeterias. 
Directors of private museums, on the other hand, have a strong incentive to increase their income, because their survival depends on sources of money like entrance fees, the restaurant, shop surpluses and additional money from sponsors and donors. If private museums generate a surplus, they are able to use it for future undertakings. As a result, we expect: (a) Private museums to rely on the market when managing their collection. Museums should actively sell paintings that do not fit into the collection anymore and use the money for buying new works of art. Private museums should have a lower stock of paintings not on display than public museums, because the opportunity costs of this stock are higher, or because private museums care more about these costs. (b) Private museums to be more concerned with attracting visitors. 'Blockbuster' exhibitions guarantee that the museum will earn money, because the preferences of a larger group of people are taken into account. Hence, the exhibitions are better arranged from a didactic point of view, appealingly presented and above all, the works of art are shown in a context which is attractive to a large crowd. (c) Private museums to emphasize the amenities for the visitors. The museum directorate is concerned with the well-being of the museum's visitors and tries to satisfy the preferences of the visitors at the lowest possible cost. The above discussion shows that private or public ownership of a museum has a considerable impact. The institutional form is closely connected with the structure of financing the museum, which influences the incentives of the museum directorate to behave in a certain manner. However, most of the museums have to be placed somewhere in the middle of the continuum between totally private and totally public museums. In the following sections, the theoretical insights from cultural economics are applied to a museum which is not exclusively private, but depends to a certain extent on public subsidies. It will therefore be interesting to test whether the prediction about the behavior of the museum directorate holds for the Beyeler Museum. 


\section{A HAPPY MARRIAGE WITH THE STATE?}

Ernst Beyeler deliberately decided not to establish an entirely private museum. Rather, he actively sought cooperation with the state. The canton Basle-Stadt and the Commune of Riehen provide a subsidy of 1.75 million Swiss Francs per year for the first ten years of operation, and grant the use of the park in which the museum is situated, its general upkeep and the administrative buildings free of charge. The most important of these decisions, namely offering the use of the park for 80 years, was democratically sanctioned in a popular vote by the citizens of the Commune of Riehen in June 1993. The museum project was approved by a large majority of the voters $(60.8 \%$ were in favor of the project, with a participation rate of $67.4 \%) .{ }^{8}$ The value of the non-monetary support from the community of Riehen is assessed at 570'000 million Swiss Francs per year (Community of Riehen, 1993).

The Beyeler museum receives between $14 \%$ and $22 \%$ of its budget in the form of monetary public grants, depending on the size of the budget, which differs according to varying sources (Kunstverein, 1999 or Eugster, 2000). This constitutes a small amount compared to other Swiss museums. The Kunsthaus in Zurich receives $46 \%$ in public grants and the Kunstmuseum in Bern $63 \%$ (Eugster, 2000). This also holds for international comparisons (with the exception of museums in the United States; see Frey and Pommerehne, 1989: 68). The degree of dependence on public support influences the behavior of the museum directorate dramatically (Frey and Pommerehne, 1989; e.g. Rosett, 1991): the less the directorate is affiliated with public bureaucracy, the greater is the incentive to generate additional income by their own and thereby to remain innovative. Of course, it is crucial how the public grants are set up. In the case of the Beyeler museum, the state does not interfere in the decisions made by the museum. All the

8 This is another instance in which art policy was put to the direct vote of the citizens, again with an outcome favorable for the arts project. See, more fully, Frey and Pommerehne (1989), chapter 10 on "Arts and Democracy" and Frey (2000), chapter 7 on "Public Support for the Arts in a Direct Democracy". 
additional income can be appropriated by the museum and it must bear any deficits. In the special case of the Beyeler museum, the deficits incurred by the museum are paid by the founder Ernst Beyeler himself. According to Beyeler, it amounts to more than one million Swiss francs per year (Mack, 2000: 58). He therefore has a strong incentive to avoid a deficit and to be innovative by attracting a large number of visitors. After the founder's death, no other individual will be 'liable' for potential losses, which weakens the incentive to be financially successful. But under the present conditions, one would expect that the museum would actively use the market to ensure its survival and to expand. In particular, the collection should be traded on the art market, the museum should engage in special exhibitions, and should offer more amenities to its visitors than public museums. These aspects will be discussed in chapters IV, V and VI.

The private-public arrangement seems to be advantageous both for the museum's founder and the state. Beyeler benefits by being able to establish a museum intimately connected with his (and his wife's) name. Moreover, he has full decision power within the terms mentioned above. The Commune of Riehen and the Canton of Basle-Stadt benefit by having a high quality collection of Modern Classics. It attracts a large number of visitors: 65,000 in 1997, 309,000 in 1998 and 250,000 in 2000. ${ }^{9}$ This exceeds the number of visitors to the Kunstmuseum in Basle with its famous collection of Holbeins, van Goghs and Gauguins. The Beyeler Museum has become an important tourist attraction. A significant number of visitors come from outside the Canton, especially from other parts of Switzerland. $60 \%$ of the visitors are foreigners, mostly from Germany, France and Italy (Eugster, 2000: 45).

A major reason for the huge popularity of the Museum is due to Renzo Piano's architecture. It was designed in close collaboration with Ernst Beyeler in order to optimally host the collection

9 The museum opened on October 18, 1997. This explains the low attendance of that particular year. If the exhibition of wrapped trees by Christo and Jeanne-Claude, which was staged in the park of the museum and could be attended free of charge, is taken into account, 608'000 people visited the museum in 1998. 
of the 170 paintings. Its cost of 65 million Swiss Francs (which includes a recent extension) was fully covered by Ernst Beyeler. Museums reached superstar status due to their impressive buildings testify the importance of architecture in attracting visitors and gaining prominence. The Getty in Los Angeles, the Guggenheim in Bilbao and Herzog and de Meuron's Tate Modern in London are pertinent examples (Economist, 2000; Frey, 2000). Beyeler was obviously well aware of the major role architecture plays for museums and therefore chose a famous architect to build his museum.

The cooperation between Beyeler and the government seems to work extremely well. It could serve as an example for elsewhere. It has not only been beneficial for the two parties involved but, above all, for prospective and actual visitors. There is little doubt that the beautiful building located in a lovely park provides an opening to the arts for people who otherwise rarely, if ever, visit museums. It has thus also served an educational mission seldom achieved by public museums in their traditional setting. The museum also contributes to the profit of the business community in Riehen and Basle, although there is only anecdotal evidence available. The question remains open whether Beyeler would have been able to run his museum without public grants. But what has been demonstrated is that with, little public money, the Beyeler museum has been able to attract a large number of visitors to high quality art exhibitions.

\section{COLLECTION POLICY WITHOUT MARKET}

It is to be expected that a private museum relies on the market for handling its collection, i.e. buying desirable objects and selling others deemed to be of lesser importance. After all, the paintings (and the few figures by Giacometti and of African and Osceanic origin) now held by the Beyeler Museum were bought on the market via normal monetary transactions. As there are no obvious external effects or high transaction costs, a private museum should keep the collection in the market sector. It must therefore come as a surprise that this is not the case. 
Rather, the Beyeler Museum's collection policy makes a point of distancing itself from the art market.

In particular, there are three aspects in which the Fondation Beyeler steers clear of the art market:

(a) De-accessioning. The core of the Beyeler collection cannot be sold. (Only secondary, nonessential, works can be sold, but only under very restricted conditions). The Museum thus robs itself of the possibility of undertaking a more flexible collection policy. Works considered less important could be sold in order to buy other works more suited to the collection, for instance to fill gaps, or to acquire an artist so far not represented. While the Beyeler Museum has only a small number of works not exhibited in its depot, it could nevertheless sell those seldom, or never, exhibited and use the proceeds to buy other works, or to finance some other activity. In contrast to other museums (see White, 1996), the Beyeler has no legal restrictions with respect to de-accessioning, ${ }^{10}$ and no third party donor restricts the reselling of paintings, which for many museums is a serious problem if they want to actively manage their collection (e.g.

O'Hagan, 1998). However, various other reasons may account for not engaging in the market:

- The founder and president, who absolutely dominates the museum's decisions, has an interest in keeping the activities of the museum clearly separate from any commercial activities at his gallery, which he is still maintaining. ${ }^{11}$ Mixing the activities together would at least partly destroy his reputation as a patron of the arts and therefore reduce his utility.

- As is the case for all museums, it is disadvantageous for the museum's directorate to engage in such monetary transactions, because it would facilitate outside intervention in particular

10 This statement must be somewhat qualified. The contract (article 3) with the state, granting the museum fixed subsidies for a period of ten years, contains a clause prohibiting the sale of any part of the collection during the period of the subsidy. However, if Beyeler had really wanted, he could probably have influenced these terms.

11 According to the New York Times (March 22, 02), Beyeler just received a guaranteed sum of \$ 19 million from the auction house Philipps for some of his Impressionists and Classical Moderns not in the Museum collection. 
on the part of politicians and the media. ${ }^{12}$ They could, for instance, more easily identify what they consider to be "mistakes" (e.g. when a painting is sold at a certain price and thereafter greatly appreciates in value). Fending off the market thus provides the Museum directorate with more discretion.

(b) Valuation. A museum's balance sheet should include the art works in its possession in order to present worthwhile information. For most museums, the value of their holdings is by far the most valuable asset. ${ }^{13}$

The Beyeler Museum does not publish the value of their collection as its main asset. ${ }^{14}$ This corresponds to the practice of all museums. This practice leads to biased allocations, as the respective costs are not fully incorporated in the calculus (e.g. Grampp, 1989). Museums tend to undervalue potential losses and overvalue benefits. As a consequence, they become too large. The reasons for not monetarizing the holdings are the same as those for not exchanging art works for money.

(c) Lending policy. Due to the many special exhibitions taking place ${ }^{15}$, museums borrow a great deal of works of art from each other. Such temporary exhibitions would be impossible without lending. The lending could be arranged on a virtual internet market, where the suppliers (the museums owning art works) offer to lend (some of) their holdings at a specific price and under specific conditions, and the demanders can choose. But it would also be possible on a smaller scale, even between two museums. Introducing prices, instead of barter, has many obvious advantages that need not be discussed further here.

12 See Frey (2000) for a politico-economic explanation of de-accessioning. General references to de-accessioning are found in O’Hagan (1998), Weil (1987) and Feldstein (1991).

13 In some cases, the opportunity cost of the land may be quite high, as museums are often situated in commercially attractive locations. See Rosett (1991) for more details.

14 The land on which the Museum is built, as well as the administrative buildings, are provided free of charge by the Commune of Riehen, but remain its property. Personal interview of one of the authors with the operative director Fausto de Lorenzo, on 19 May, 2002.

15 In 2001, there were almost 700 special exhibitions world-wide, which attracted on average more than 100 visitors daily (The Art Newspaper, 2002). Taking all special exhibitions into account, the number for Europe easily exceeds 1100 for 1993/94 (Frey and Vautravers-Busenhart, 2000: 67-71). 
Nonetheless, the Beyeler Museum is very strict in its policy of only lending in exchange for works of art received from other museums. This corresponds to the general practice of all museums (Caves, 2000: 345-347). ${ }^{16}$ The reasons for refraining from pricing are quite straightforward. The knowledge and relationship capital accumulated over many years by both Beyeler himself, as well as his curators, would lose much of its value. In order to mount a special exhibition, it would no longer be necessary to have extensive personal contacts; it would suffice to have an idea for an exhibition which could be marketed well. The market for art exhibitions would be open to any entrepreneur. Without pricing for lending works of art, the market for exhibitions is restricted to museums with a collection of their own from which they can offer works in exchange. It could, however, be argued that such market restrictions are a public good and that one particular actor would benefit from not keeping to the rule of only bartering art works. But the "museum and exhibition world" is made up of a rather small number of people who essentially all know each other. Anyone breaking the rule would be punished by the members of this "cartel". ${ }^{17} \mathrm{He}$ or she would lose prestige and recognition. As the other persons involved form a crucial reference group, few, if any, museum actors have an incentive to break the rules.

The observation that the private Beyeler Museum distances itself from the art market when managing its collection is surprising in the light of a pure institutional approach to museum behavior. The Beyeler Museum, as a private museum, does not differ from pure public museums in that respect. However, it is possible to explain the behavior of Beyeler by taking into account that the director's utility depends on his reputation as a patron of the arts and that he built up a large network, which would be useless if one would trade paintings for financial

16 An exception are Russian museums. Western museums are prepared to waive their rule of not paying money for lending works of art because they acknowledge that Russian museums are extremely short of cash. Revenues are one of the only possibilities of financing necessary expenditures in order to maintain their museums and collections. 
compensation. He could even be punished by other museum directors for violating the rules of the 'museum world'. Above all, the Beyeler Museum is not entirely private, but depends on public grants, as will be discussed in the following section.

To summarize, the case of the Beyeler museum shows that even private museums are restricted in various ways of relying on the market for running their museum. The too trivial view that private museums act totally differently from public ones does not hold. In discussing the behavior of private or public museums, one has to focus more on the museums which are neither totally private nor totally public, and where predictions about their behavior are much more complex. The Beyeler museum abstains from the market, although mostly privately founded.

\section{THE SELF-DYNAMICS OF SPECIAL EXHIBITIONS}

The Museum was established and designed to host Beyeler's collection. In view of the generally acknowledged high quality of the paintings (and a few sculptures) they could well have left it at that. While the number of visitors would have been smaller it is a fair guess that the Museum would have occupied an important place among museums in Switzerland and far beyond.

But, in actual fact, the Museum developed in a somewhat unexpected direction. The Museum undertakes a considerable number of special exhibitions loosely connected (if at all) to the collection $^{18}$. The first one was Christo and Jeanne-Claude, who wrapped trees in the Museum park. It was followed by special exhibitions featuring Renzo Piano, Jasper Johns, Wassily Kandinsky, Roy Lichtenstein, Cezanne, Andy Warhol and Mark Rothko. Alone in 2002, there

17 Punishment is a second order public good (Elster, 1999: 41). It is well established that people are willing to provide it under many conditions. See Fehr and Gächter (2000) for experimental evidence, and Osterloh, Rota and von Wartburg (2001) for real life evidence (contributions to an open source system).

18 It is always possible to establish some kind of relationship between the 170 paintings and other art works in the collection and the topic of some special exhibition. What is argued here is that the artistic importance of the collection is quite independent of the special exhibitions mounted. 
were, or will be, major exhibitions of paintings by Anselm Kiefer, Claude Monet and Ellsworth Kelly. The organization of these special exhibitions has become a substantial part of the activity of the Museum staff; it binds a lot of energy, attention and material resources. The special exhibitions are financially attractive in the sense that they generate considerable additional revenue from the entrance fees. It is less clear whether the Museum makes a net profit. It is known in general that special exhibitions not only require much in the way of additional human and material resources, but are also costly in terms of transport and insurance. The Museum directorate does not disclose any figures in this respect, so that the observer is forced to speculate on the basis of evidence from elsewhere. The reason for not disclosing the financial aspects of these important Museum activities can be taken to lie in an effort on the part of the directorate to shield themselves from possible criticism from outside.

The Beyeler Museum seems to have been caught in a self-propelling process which continually drives itself. The wrapped trees exhibition mounted by Christo and Jeanne-Claude was a huge success in terms of media attention and numbers of visitors (in that year, 1998, 608'000 persons visited the museum and the park). The Museum directorate foresaw that the number of visitors (to which they attribute much attention ${ }^{19}$ ) would markedly fall if there were no further special exhibitions. The Museum to some extent fell prey to their own success and the resulting expectations. Moreover, special exhibitions are in the interests of the museum staff, as they allow them to gain prominence in their reference group ${ }^{20}$. Each major new special exhibition is an event closely watched and evaluated by the museum community. In contrast, once a permanent collection has been established, it does not gain any new or additional attention. The same applies, but even more, to the media, which play an increasingly important role for the museum world. As a result, the Christo/Jeanne-Claude show was followed by further special

\footnotetext{
19 Personal interview of the authors with curator Philippe Büttner and art historian Daniel Kramer, on 13 March 2002.

20 See Frey (2000), Frey and Pommerehne (1989).
} 
events. Once started, it is difficult, if not impossible, to stop the process. While the expectations created by the media certainly play a role, a practical reason is that the whole artistic and commercial administration has been geared to the high level of activity accompanying the special exhibitions. It is easier to pursue the path already taken than to get rid of excess capacity. The process thus leads to an increase in staff, which is difficult to reduce afterwards, so further and even more successful exhibitions are needed.

It could be argued that Ernst Beyeler could have stopped the trend to rely more and more on special exhibitions. Without a doubt, he has the power to do so. The reason why he chose to tolerate, or even support, such additional activity probably is due to the fact that he enjoys the prominence going with each new exhibition. As a most successful art dealer, his behavior is not solely intrinsically motivated, but also responds to such external factors as gaining attention in the art world and high media recognition (though he would probably deny any such motivation if asked).

The result is a museum designed to host a high quality collection but with a strong, and perhaps even increasing, emphasis on special exhibitions. It could be argued that while the initial collection is really unique, the special exhibitions are not necessarily so. Indeed, mounting special exhibitions has become a feature of almost all museums, including public ones. ${ }^{21}$ Many of the special exhibitions organized in the Beyeler Museum could have been organized perhaps equally well by other institutions. In this sense, the museum may even over time have lost some of what distinguishes it from other museums.

21 Frey and Vautravers-Busenhart (2000). 


\section{VISITORS' AMENITIES}

From an institutional perspective, the predictions about revenue generating activities are straightforward: private museums should generate more additional revenue than public museums, because they can fully retain the additional revenue. In contrast, public museums either have to hand the additional income over to the general public treasury, or at least risk having their future subsidies reduced if not completely cut. In this respect, the Beyeler Museum differs little from public museums; it does not show much in the way of innovative activities to generate revenues. Nevertheless, some institutional differences are visible.

A profit-oriented private museum seeks to maximize revenue by differentiating entrance fees according to presumed or estimated price elasticity of demand. This has to some extent been done by the Beyeler Museum. With respect to time, the entrance fee is lower in the evening hours (6 to 8 p.m.) and higher at weekends. Seniors citizens, children and students pay less, and entrance is free for the members of the Beyeler Museum's "ArtClub". No higher entry fees are charged for special exhibitions; tickets can be ordered online, paid by credit card, but only allow entry at specified times. While such price differentiation goes a step further than in many public museums, it is not unique. The same holds for outsourcing various activities, such as the ticket office, entry control, the Museum shop, cleaning and the restaurant. The same activities have also been outsourced in some public museums, provided they have a certain amount of independence. The reason outsourcing is less prevalent in public museums lies partly in the fact that institutions differ but also in the fact that newly established museums (which are often private) have more possibilities engaging in such new ways of running a museum. The Beyeler museum is able to outsource even the conservation and restoration of the paintings to the public Kunstmuseum of Basle at a 'reasonable price' (article 7 in the contract between the Museum and the canton of Basle). 
But Beyeler is engaging in certain activities, which public museums do not provide to the same extent. The restaurant is of high quality (one Michelin star). Therefore, the outsourced restaurant and the museum mutually benefit from each other. The Beyeler museum is also organizing cultural journeys to various destinations in Europe in connection with the national Swiss carrier. In 2002, they offer trips to Vienna, Copenhagen and Moscow. This collaboration allows the museum to offer an additional good, which is not directly connected to the core task of the museum.

\section{WHAT CAN BE LEARNT?}

On the basis of the economic analysis of the arts, this paper studies one particular museum, the highly successful Beyeler Museum located in Riehen near Basle, founded in 1997 and housed in a building designed by the famous architect, Renzo Piano, to exhibit a first rate collection of paintings.

The analysis undertaken in this paper allows us to draw seven conclusions of interest to all art museums (and beyond).

(1) An essentially private museum, like the one "belonging" to Beyeler, is - as expected able to undertake more market oriented policies than public museums. This is shown, in particular, with respect to the amenities provided for the visitors, such as more flexible opening hours and an excellent restaurant. However, public museums have been able to "imitate" at least some of these more market oriented policies, and sometimes the major reason why they are unable to go any further lies in the buildings they are attached to. Thus, the differences in policy may more aptly reflect the founding date than the differences in the institutional setting. 
(2) Many, if not most, newly founded museums intimately combine their collection with appropriate architecture. The Beyeler Museum followed this trend, thereby strongly enhancing its attraction to a more general public, in particular tourists, who otherwise rarely visit art museums.

(3) Considering that the Beyeler Museum is privately run (there is virtually no public intervention in its policy), one could expect that it would also behave in a market oriented way with respect to its collection policy. This is, however, not the case at all. The collection policy does not differ from what has been undertaken in the past and by purely public museums: there is no de-accessioning; the collection is not valued in monetary terms; and any borrowing and lending take place by exchange, not by offering financial compensation. It must be concluded that such a museum policy is little related to the institutional difference between private and public museums. Rather, it is specific to running (art) museums. We have identified the reputation of the museum management, and the associated accumulated human capital, as the major reason why the collection policy is not based on market principles.

(4) Ernst Beyeler founded his museum to house a well-defined, first rate collection of paintings (and some sculptures). Piano's building has been explicitly designed for that purpose. But the activities of the Beyeler Museum today are oriented in quite a different direction. Much time, effort and attention is consumed by the continuous special exhibitions mounted. They are designed to be "blockbusters" in the sense that the number of visitors plays a major role. This is perfectly in line with the institution of a private museum, which is able to retain all revenues (while many public museums must contribute all, or at least a substantial part, of the revenue to the general government finances). Such behavior focussing on the number of visitors, constitutes a self-propelling process which is difficult, or impossible, to stop. In particular, the Beyeler Museum has 
fallen prey to the huge number of visitors coming to the opening exhibition by Christo and Jeanne-Claude. Both the museum founder, as well as the curators and the rest of the museum staff, have a strong interest in keeping up the number of visitors. It provides recognition in the "museum world" and attracts continuous media attention. Once this process has started, a noticeable reduction in the number of visitors would be perceived to be close to failure and tending to reduce prestige.

(5) It is unclear whether the special exhibitions contribute to net profits, because the financial accounts of the Museum are not revealed. If they are profitable, they contribute to the Museum's sustainability (at least as long as other museums are less successful in such a policy). But if they are not profitable, they may endanger the future of the Museum as it is designed at present. At the present time, the founder is said to invest more than 1 million Swiss Francs (close to 700,000 Euros) each year. When this additional source of support ends, the most likely development will be that the government (the Commune of Riehen and the Canton Basle-Stadt) will have to substantially increase its subsidy. But this will certainly involve more public intervention, including ongoing museum policy.

(6) The Beyeler Museum demonstrates that intermediate forms of governance between private and public may work extremely well. Both the public and the founder may derive substantial benefits. A small amount of public money has produced a very large effect both in terms of further establishing Basle as a canton of art and attracting large numbers of tourists. But, as argued above, this "happy marriage" may not be sustainable in the long run.

(7) The whole endeavor has been sanctioned by a popular referendum. This is another instance where the voters as a whole have supported new artistic projects. It goes against the still widely held notion that only the cultural and political "élite" are able to decide on art. 


\section{REFERENCES}

Art Newspaper, The (2002) World-wide exhibition attendance figures for 2001, The Art Newspaper International Edition, www.theartnewspaper.com.

Becker, G. S. (1976) The Economic Approach to Human Behavior, Chicago: Chicago University Press.

Caves, R. E. (2000) Creative Industries: Contracts Between Art and Commerce, Cambridge, USA and London, UK: Harvard University Press.

Economist, The (2000). Museums galore, The Economist, February $19^{\text {th }}, 82-85$.

Elster, J. (1999) Alchemies of the mind. Rationality and the emotions, New York: Cambridge University Press.

Eugster, C. (2000) Museen: Organisation, Finanzierung und Betriebsgestaltung, Working Paper of Institut de Hautes Etudes en Administration Publique.

Fehr, E. and S. Gächter. (2000) Cooperation and Punishment in Public Goods Experiments. American Economic Review, 90, 980-994.

Feldstein, M. (ed.) (1991) The Economics of Art Museums, Chicago: University of Chicago Press.

Frey, B. S. (2000) Arts \& Economics: Analysis \& Cultural Policy, Berlin et al.: Springer Verlag.

Frey, B. S. (2000) For Art's Sake - Open Up the Vaults, In: B. S. Frey. Arts \& Economics: Analysis \& Cultural Policy, Berlin et al.: Springer: 35-47.

Frey, B. S. (1999) Economics as a Science of Human Behaviour. Towards a New Social Science Paradigm, Extended Second Edition, Boston/Dordrecht/London: Kluwer Academic Publishers.

Frey, B. S. (1994) Cultural Economics and Museum Behaviour. Scottish Journal of Political Economy, 41 (3), 325-335.

Frey, B. S. and W. W. Pommerehne (1989) Muses and Markets: Explorations in the Economics of the Arts, 1990 reprint, Oxford: Blackwell. 
Frey, B. S. and I. Vautravers-Busenhart (2000) Special Exhibitions and Festivals: Culture's Booming Path to Glory. In: B. S. Frey, Arts \& Economics: Analysis \& Cultural Policy, Berlin et al.: Springer: 67-93.

Grampp, W. D. (1989) Pricing the Priceless. Art, Artists and Economics, New York: Basil Books.

Hirshleifer, J. (1985) The Expanding Domain of Economics, American Economic Review, 75 (May), 53-68.

Kunstverein, Schweiz. (ed.) (1999) Museumsland Schweiz: Wachstum ohne Grenzen? Zürich: Schweiz. Kunstverein.

Mack, G. (2000) 'Ich habe Erfahrung und merke einfach, was ankommt' (Interview with Ernst Beyeler), Cash, August 25, 58.

Montias, J. M. (1973) Are Museums Betraying the Public's Trust? Museums New (May), 25-31. Reprinted in the Journal of Cultural Economics, 19 (1995), 71-80.

O'Hagan, J. W. (1998) Art Museums: Collections, Deaccessioning and Donations, Journal of Cultural Economics, 22 (2-3), 197-207.

Osterloh, M., S. Rota and M. von Wartburg (2001) Open Source - New Rules in Software Development. Working Paper. Institute for Research in Business Administration. University of Zurich.

Rosett, R. N. (1991) Art Museums in the United States: A Financial Portrait, In The Economics of Art Museums, M. Feldstein, ed., Chicago and London: The University of Chicago Press: 129-177.

Stigler, G. J. (1984) Economics - The Imperial Science? Scandinavian Journal of Economics, $86,301-13$.

Weil, S. E. (1987) Deaccession Practices in American Museums, Museum News, 65 (3), 44-50.

White, J. L. (1996) When It's OK To Sell the Monet: A Trustee-Fiduciary-Duty Framework for Analysing the Deaccessioning of Art To Meet Museum Operating Expenses, Michigan Law Review, 94 (4), 1041-1066. 